\title{
S-Klotho level and physiological markers of cardiometabolic risk in healthy adult men
}

\author{
Agnieszka Żelaźniewicz ${ }^{1}$, Judyta Nowak-Kornicka ${ }^{1}$, Bogusław Pawłowski $^{1}$ \\ ${ }^{1}$ Department of Human Biology, University of Wrocław, Wrocław, Poland
}

Correspondence to: Agnieszka Żelaźniewicz; email: agnieszka.zelazniewicz@uwr.edu.pl

Keywords: aging, healthspan, longevity, early marker, cardiometabolic risk

Received: June 15, $2021 \quad$ Accepted: January 17, $2022 \quad$ Published: January 30, 2022

Copyright: (c) 2022 Żelaźniewicz et al. This is an open access article distributed under the terms of the Creative Commons Attribution License (CC BY 3.0), which permits unrestricted use, distribution, and reproduction in any medium, provided the original author and source are credited.

\begin{abstract}
S-Klotho is perceived as a biomarker of healthy aging that has been shown to be inversely associated with cardiometabolic risk in elderly individuals. The aim of this study was to test if s-Klotho level is associated with cardiometabolic risk markers in younger healthy men in order to verify the possible role of s-Klotho level as an early marker of cardiometabolic risk. A cross-sectional study was conducted among 186 healthy men $\left(M_{\text {age }}=35.33, S_{\text {age }}=3.47\right)$ from a Western urban population. Serum basal levels of $s$-Klotho, lipid profile, homocysteine, glycemia markers, C-reactive protein, liver transaminases and creatinine were evaluated. Also, blood pressure was measured and cardiometabolic risk score and homeostatic model assessment for insulin resistance (HOMA-IR) were calculated. Testosterone and cortisol levels, self-reported psychological stress, physical activity, smoking in the past, alcohol use and body adiposity were controlled for. We found no relationship between levels of $s$-Klotho and physiological markers of cardiometabolic risk in the studied population. The results were similar when controlled for adiposity, testosterone level, physical activity, alcohol use and smoking in the past. We suggest that s-Klotho level is not an early marker of cardiometabolic risk in younger middle-aged healthy men.
\end{abstract}

\section{INTRODUCTION}

The $\alpha$-Klotho gene has been described as an "aging suppressor" gene in mice, encoding a protein, s-Klotho, with multiple pleiotropic effects [1]. A defect in mouse $\alpha$-Klotho gene expression conferred shortened lifespan and progeroid phenotype linked with multiple disorders resembling human aging. This phenotype included organ and skin atrophy, infertility, atherosclerosis, vascular endothelial dysfunctions, vascular calcification, cardiac hypertrophy, decreased bone mineral density, sarcopenia, glucose metabolism disorders, and impaired cognition. In contrast, overexpression of $\alpha$-Klotho gene significantly extended both healthspan and lifespan in mice [2-4].

The systemic effects of $\alpha$-Klotho appear to be primarily exerted by its circulating form, soluble Klotho protein (s-Klotho), expressed predominantly in kidneys and to a lesser extent in the brain, skeletal muscle, urinary bladder, aorta, gonads, and thyroid gland [1]. S-Klotho functions as a humoral factor through binding to its cellsurface receptor and as an enzyme acting on cell-surface glycoproteins activating (e.g. calcium channel proteins) or inhibiting (e.g. phosphate transporters) cell surface receptors and enzymes in multiple tissues and organs [5-8]. In humans, s-Klotho has been shown to improve kidney functioning [9], systemic phosphate homeostasis [10] and glucose metabolism [11], to inhibit insulin/ IGF-1 signaling pathways [12], to act as co-receptor of the fibroblast growth factor 23 [13], to decrease intracellular oxidative stress [14] and chronic inflammation [15-18]. Thus, the effect of s-Klotho on longevity and healthspan may result from its metabolic functions as hyperphosphatemia, oxidative stress, chronic inflammation, imbalanced glucose metabolism, decreased IGF-1 levels accelerate aging in humans [17-21]. As such, s-Klotho level has emerged as a 
biomarker of healthy ageing, inversely linked with chronological age and a number of age-related illnesses both in model organisms and in humans and an intriguing target for interventional studies $[15,22]$. This is especially important as life expectancy has significantly increased in developed countries during the last century with the consequent increment of chronic disease incidence [23].

Oxidative stress and chronic inflammation are positively linked with such age-related conditions as type 2 diabetes and cardiovascular disorders $[24,25]$, the dominant metabolic diseases worldwide with expected increases in prevalence [23]. Due to its anti-inflammatory and antioxidant properties s-Klotho is expected to play a protective role against cardiometabolic diseases [26, 27] for instance by maintaining endothelial wall homeostasis and integrity, ameliorating vascular calcification, improving kidney functions [28-30] or insulin sensitivity [11]. However, the possible role of s-Klotho as an early marker of cardiometabolic risk has not been proven yet.

Previous research has shown that polymorphisms in the human Klotho gene are associated with various cardiovascular events and metabolic syndrome as well as with cardiometabolic risk factors, such as reduced HDL level and elevated blood pressure [28, 31]. Also, sKlotho level has been shown to be inversely associated with the prevalence of cardiometabolic diseases in adults aged 24-102 years [26] or stress-induced cardiac hypertrophy and remodeling [32]. On the other hand, Liang et al. [33] found no relationship between s-Klotho level and hypertension or arterial stiffness in general Chinese population. One of the possible reasons for these contradictory results may be a differential effect of age on the association between s-Klotho and cardiometabolic disease [34]. Recently, Amaro-Gahete et al. [35] showed that s-Klotho level is negatively related with cardiovascular risk and insulin resistance markers level in a group of healthy men and women of 40-65 years but not in young adults of 18-25 years. This suggests that s-Klotho may serve as a marker of cardiometabolic status in middle-aged but not very young individuals. S-Klotho level has been also shown to be related with early indicators of atherosclerosis such as carotid artery intima-media thickness, flow-mediated dilation of brachial artery and epicardial fat thickness in healthy adults of median age 32 years, however on a relatively small sample size $(\mathrm{N}=50)$ [36]. S-Klotho level has been also shown to be inversely related with the probability of developing heightened glucose level and hyperglycemia in 80 males of $40-80$ years [37]. Thus, so far s-Klotho level has been shown to be lower in individuals with cardiometabolic disease $[26,32]$ or to be related with cardiometabolic risk in individuals of older age [35], but to our knowledge no study has investigated the relationship between s-Klotho level and physiological markers of cardiometabolic risk in younger middle-aged men. If s-Klotho level is a reliable marker of current and future health in relatively young individuals it may help to identify individuals with an increased risk of developing age-related disorders and may serve as a measure of relative fitness, predicting disability in later life. Studies on early markers of agerelated disorders are especially important for early interventions in western populations, where life expectancy has increased in recent decades, however, the fundamental aging process remains unchanged [38].

In this study we tested for the relationship between s-Klotho level and markers of cardiometabolic risk in healthy men between 30-45 years in order to verify if s-Klotho may be used as an early marker of cardiometabolic risk in this age range. Thus, we aimed to replicate the work of Amaro-Gahete et al. [35] on a group of young middle-aged men. Studies on anti-ageing factors in older middle-aged or elderly populations are compromised by the fact that the majority of participants already have some form of agerelated disease, which may impact the levels of these factors [39]. Participants' age range in this study (30-45 years) will allow to verify if the relationship between sKlotho and cardiometabolic risk markers levels can also be detected in younger but not too young individuals. The age of onset of age-related cardiometabolic diseases decreases in western countries [40, 41], increasing in thirties $[42,43]$. The onset of these disorders may occur even 9-12 years before its clinical diagnosis [44]. Thus, it is important to identify early markers of such diseases (and of the risk of their development) for prophylactic purposes, as they may no longer be diseases primarily of the elderly.

Cardiometabolic risk was evaluated with biomarkers for risk of developing cardiovascular problems, impaired glucose tolerance and liver dysfunction. As s-Klotho level decreases in individuals with kidney damage [45] we have controlled for possible renal dysfunctions based on estimated glomerular filtration rate (eGFR) and creatinine levels. We have also controlled for factors that have been shown to be related with s-Klotho level and cardiometabolic risk, such as chronological age [46], body composition [47], physical activity [48], testosterone level [49-51], alcohol use [52] and psychological stress level [53].

\section{RESULTS}

\section{Descriptive statistics}

Descriptive statistics of the main variables are presented in Table 1 (see also Supplementary Materials 
Table 1. Descriptive statistics of the main variables ( $\mathrm{N}=186)$.

\begin{tabular}{lcccc}
\hline & M & SD & Min & Max \\
\hline Age [years] & 35.33 & 3.47 & 29.73 & 44.29 \\
S-Klotho [pg/ml] & 1144.38 & 461.85 & 306.70 & 2686.50 \\
BMI $^{1}[\mathrm{~kg} / \mathrm{m} 2]$ & 25.66 & 3.52 & 18.62 & 37.46 \\
Cardiometabolic risk score & 0.01 & 0.69 & -1.47 & 2.90 \\
Total cholesterol [mg/dl] & 193.10 & 36.53 & 116.00 & 340.00 \\
Homocysteine $[\mu \mathrm{mol} / \mathrm{l}]$ & 13.62 & 2.80 & 8.80 & 26.35 \\
hsCRP $^{2}[\mathrm{mg} / \mathrm{L}]$ & 1.20 & 1.23 & 0.01 & 6.49 \\
HbA1c $^{3}[\mathrm{mmol} / \mathrm{mol}]$ & 34.08 & 2.85 & 27.00 & 42.00 \\
Glucose to insulin ratio $_{\text {HOMA-IR }}^{4}$ & 12.64 & 5.89 & 3.67 & 34.54 \\
AST/ALT & 2.12 & 1.19 & 0.41 & 7.04 \\
Creatinine [mg/dl] & 1.01 & 0.33 & 0.32 & 2.44 \\
Total testosterone [ng/dl] & 0.94 & 0.11 & 0.65 & 1.40 \\
Stress [2-14] & 487.15 & 174.86 & 135.30 & 1157.00 \\
\hline
\end{tabular}

${ }^{1} \mathrm{BMI}$, Body Mass Index.

${ }^{2} \mathrm{hsCRP}$, high sensitivity C-reactive protein level.

${ }^{3} \mathrm{HbA1C}$, glycated hemoglobin level.

${ }^{4} \mathrm{HOMA}-\mathrm{IR}$, homeostatic model assessment for insulin resistance.

${ }^{5}$ Aspartate aminotransferase (AST) to alanine transaminase (ALT) ratio.

for descriptive statistics of additional variables Supplementary Table 1).

Individuals who smoked in the past had higher cardiometabolic risk score $(\mathrm{M}=0.25, \mathrm{SD}=0.79)$ compared with individuals who have never smoked $(\mathrm{M}=-0.05$, $\mathrm{SD}=0.66)(\mathrm{t}(184)=-2.34, p=0.02)$. Also, individuals who smoked in the past had higher total cholesterol level $(\mathrm{M}=2.31, \mathrm{SD}=0.07)$ compared with individuals who have never smoked $(\mathrm{M}=2.27, \quad \mathrm{SD}=0.08) \quad(\mathrm{t}(184)=-2.35$, $p=0.02$ ). The two groups of men did not differ in terms of s-Klotho, mean blood pressure (MBP), triglycerides, high-density lipoprotein (HDL), homocysteine, hsCRP, glycated hemoglobin (HbA1c), glucose to insulin ratio, homeostatic model assessment for insulin resistance (HOMA-IR), creatinine, aspartate aminotransferase to alanine transaminase ratio (ALT/AST) or total testosterone level (in each case: $p>0.09$ - See Supplementary Table 2 in Supplementary Material).

Individuals who were physically active had lower cardiometabolic risk score $(\mathrm{M}=-0.12, \quad \mathrm{SD}=0.63)$ compared with individuals who were inactive $(\mathrm{M}=0.15$, $\mathrm{SD}=0.74) \quad(\mathrm{t}(184)=-2.68, \mathrm{p}=0.008)$. Individuals who were physically active had lower total cholesterol level (LOG values: $\mathrm{M}=2.26, \mathrm{SD}=0.08$ ) compared with individuals who were inactive (LOG values: $\mathrm{M}=2.30$, $\mathrm{SD}=0.08) \quad(\mathrm{t}(184)=-4.11, \mathrm{p}<0.001)$. Also, individuals who were physically active had lower high sensitivity C-reactive protein (hsCRP) level (LOG values: $\mathrm{M}=-$ $0.26, \mathrm{SD}=0.56$ ) compared with individuals who were physically inactive (LOG values: $\mathrm{M}=-0.08, \mathrm{SD}=0.54$ ) $(\mathrm{t}(184)=-2.26, \mathrm{p}=0.02)$. Individuals who were physically active had higher glucose to insulin ratio (LOG values: $\mathrm{M}=1.09, \mathrm{SD}=0.21$ ) and lower HOMA-IR level (LOG values: $\mathrm{M}=0.22, \mathrm{SD}=0.24)$ compared with individuals who were inactive (LOG G:I: $\mathrm{M}=1.02, \mathrm{SD}=0.19$; $\mathrm{LOG}$ HOMA-IR: $\mathrm{M}=0.32, \mathrm{SD}=0.22)$ (LOG G:I: $\mathrm{t}(184)=2.56$, $\mathrm{p}=0.01$; LOG HOMA-IR: $\mathrm{t}(184)=-2.90, \mathrm{p}=0.004)$. Individuals who were physically active had higher ALT/AST ratio $(\mathrm{M}=0.01, \mathrm{SD}=0.14)$ compared with individuals who were inactive $(\mathrm{M}=-0.05, \mathrm{SD}=0.14)$ $(\mathrm{t}(184)=3.08, \quad \mathrm{p}=0.002)$. Individuals who were physically active had also higher total testosterone level $(\mathrm{M}=2.69, \mathrm{SD}=0.14)$ compared with those who were inactive $(\mathrm{M}=2.63, \mathrm{SD}=0.17) \quad(\mathrm{t}(184)=2.64, \mathrm{p}=0.009)$. The two groups also differed in terms of triglycerides level, fat mass index, waist circumference, glucose, insulin and ALT levels but did not differ in terms of sKlotho level, age, body mass index (BMI), lean mass, MBP, HDL, homocysteine, HbA1c, AST levels or stress (in each case: $p>0.06$ - See Supplementary Table 3 in Supplementary Materials).

Men who rarely drink alcohol had higher levels of sKlotho level compared with men who sometimes and men who often drink alcohol $(\mathrm{F}(2,183)=6.90, p=0.001)$. Men who sometimes drink alcohol and men who often drink alcohol did not differ in terms of s-Klotho level $(p>0.05)$. The three groups of men also differed in terms of triglycerides level but did not differ in terms of other measures of cardiometabolic risk $(p>0.08$ in each case - 
See Supplementary Table 4 in Supplementary Materials for detailed statistics).

S-Klotho level was not related with chronological age, BMI, fat or lean body mass, psychological stress, testosterone level, or creatinine level (Table 2). The results of correlation analysis for the relationship between age, testosterone, stress, BMI and cardiometabolic risk markers are presented in Supplementary Materials (Supplementary Table 5).

\section{Klotho level and cardiovascular risk markers}

There was no relationship between s-Klotho level and cardiometabolic risk score, total cholesterol, homocysteine or hsCRP level (Table 2). There was also no correlation between s-Klotho level and the level of clinical markers of glycemia or liver functioning (Table 2). None of the cardiometabolic risk markers was related with s-Klotho level. The results of correlation analysis between s-Klotho level and additional variables are presented in Supplementary Materials (Supplementary Table 6).

\section{Klotho level and cardiovascular risk markers, controlled for confounders}

There was no relationship between s-Klotho level and cardiometabolic risk score (Table 3 - Model 1), total cholesterol (Table 3 - Model 2), homocysteine (Table 3 Model 3), hsCRP (Table 3 - Model 4), HbA1c (Table 3 - Model 5), glucose to insulin ratio (Table 3 - Model 6), HOMA-IR (Table 3 - Model 7), when adjusted for age, BMI, alcohol use, testosterone level and physical activity. Also, s-Klotho was not related with MBP, triglycerides, HDL, glucose, insulin, ALT or AST (See Supplementary Materials for the detailed results Supplementary Table 6). S-Klotho was positively related with ALT/AST ratio when adjusted for age, BMI, alcohol use, testosterone level and physical activity (Table 3 - Model 8), however, the $\mathrm{p}$ value would exceed the level of 0.05 after Bonferroni correction for multiple comparisons. The models using fat mass index or lean mass index instead of BMI showed similar results, thus are not presented.

Additionally, we have run a regression analysis to test for the relationship between s-Klotho and testosterone level. S-Klotho and testosterone level correlated positively when controlled for BMI, physical activity, alcohol use and age (Table 4 and Supplementary Table 7).

\section{DISCUSSION}

The results of our study showed no relationship between s-Klotho level and physiological markers of cardiometabolic risk in healthy, non-smoking men form an urban, western population, aged $30-45$ years. The results were similar when controlled for BMI, testosterone level, physical activity, alcohol use and smoking in the past.

Previous research has shown that s-Klotho may be an important marker of ongoing cardiovascular disease [26, 31, 54, 55] - although see also [33] and [56] for no relationship] or even a therapeutic agent for the treatment of CVD [57]. However, the results of our and previous studies suggest that its role as an early marker of cardiovascular disease risk in healthy individuals may depend on age. Amaro-Gahete et al. [35] showed a negative relationship between s-Klotho and cardiometabolic risk markers levels in middle-aged adults of 40-65 years but not in young adults of 18-25 years. Semba et al. [26, 54] reported a strong inverse association between S-Klotho level and the likelihood of developing cardiovascular disease, as well as risk of all-cause mortality, in a large cohort of adults aged over 65 years. We suggest that s-Klotho level may serve as an early marker of cardiometabolic risk in healthy middle-aged adults (at least over 40 years) but not in relatively young adults. Further large-scale prospective studies are required to verify the relationship between sKlotho and cardiometabolic risk markers levels in different age groups of healthy individuals.

We found also no relationship between s-Klotho level and lifestyle-related risk factors of cardiometabolic disease such as smoking in the past, lack of physical activity or self-assessed psychological stress. On the other hand, these factors (except psychological stress) were related with cardiometabolic risk score, lipid profile and in case of physical activity also with markers of glucose metabolism, liver functioning and hsCRP level. This may suggest that these markers may be more reliable risk factors of cardiometabolic risk in healthy adult men between 30 and 45 years compared with s-Klotho level. S-Klotho level was only negatively related with frequency of alcohol drinking, confirming the results of previous studies [52].

The positive relationship between s-Klotho and testosterone level was observed when adjusted for age, BMI, physical activity, and alcohol use. Furthermore, testosterone level was negatively related with majority of cardiometabolic risk biomarkers level (except homocysteine level). Ageing beyond 35-40 years is associated with gradual decline in testosterone level in men [58] and low testosterone level appears to be a biomarker of poor health in older men associated with acute and chronic pathologies, including cardiometabolic disorders, and also with high risk of all-cause mortality $[49,50,59,60]$. Previous research showed that 
Table 2. The results of correlation analyses for the relationship between s-Klotho and markers of cardiometabolic risk and controlled variables ( $\mathrm{N}=186$ ).

\begin{tabular}{|c|c|c|}
\hline & $\mathbf{r}$ & $p$ \\
\hline Age [years] & 0.09 & 0.20 \\
\hline $\mathrm{BMI}^{1}\left[\mathrm{~kg} / \mathrm{m}^{2}\right]$ & 0.02 & 0.78 \\
\hline Cardiometabolic risk score & -0.03 & 0.71 \\
\hline Total cholesterol LOG $[\mathrm{mg} / \mathrm{dl}]$ & -0.05 & 0.47 \\
\hline Homocysteine LOG $[\mu \mathrm{mol} / 1]$ & 0.05 & 0.52 \\
\hline $\mathrm{hsCRP}^{2} \mathrm{LOG}[\mathrm{mg} / \mathrm{L}]$ & -0.12 & 0.10 \\
\hline $\mathrm{HbA} 1 \mathrm{c}^{3}[\mathrm{mmol} / \mathrm{mol}]$ & -0.02 & 0.78 \\
\hline Glucose to insulin ratio LOG & -0.06 & 0.41 \\
\hline HOMA-IR ${ }^{4}$ LOG & 0.09 & 0.24 \\
\hline $\mathrm{ALT} / \mathrm{AST}^{5} \mathrm{LOG}$ & 0.13 & 0.07 \\
\hline Creatinine LOG $[\mathrm{mg} / \mathrm{dl}]$ & 0.13 & 0.08 \\
\hline Total testosterone LOG $[\mathrm{ng} / \mathrm{dl}]$ & 0.14 & 0.06 \\
\hline Stress [2-14] & 0.06 & 0.40 \\
\hline
\end{tabular}

${ }^{1} \mathrm{BMI}$, Body Mass Index.

${ }^{2}$ hsCRP, high sensitivity C-reactive protein level.

${ }^{3} \mathrm{HbA1c}$, glycated hemoglobin level.

${ }^{4} \mathrm{HOMA}-\mathrm{IR}$, homeostatic model assessment for insulin resistance.

${ }^{5}$ Aspartate aminotransferase (AST) to alanine transaminase (ALT) ratio.

Table 3. The results of regression analysis of the relationship between s-Klotho level and measures of cardiometabolic risk, adjusted for age, BMI, alcohol use, physical activity and testosterone level ( $\mathrm{N}=186$ ).

\begin{tabular}{|c|c|c|c|c|}
\hline & $\boldsymbol{\beta}$ & $\operatorname{SE}(\beta)$ & $\mathbf{t}(\mathbf{1 7 9})$ & $p$ \\
\hline \multicolumn{5}{|c|}{ Model 1: Dependent variable: cardiometabolic risk score: $F(6,179)=41.65$, adj. $R^{2}=0.57, p<0.001$} \\
\hline S-Klotho LOG [pg/ml] & 0.01 & 0.05 & 0.16 & 0.87 \\
\hline Age [years] & -0.003 & 0.05 & -0.06 & 0.95 \\
\hline BMI ${ }^{1}\left[\mathrm{~kg} / \mathrm{m}^{2}\right]$ & 0.62 & 0.06 & 11.28 & $<0.001$ \\
\hline Alcohol use & 0.05 & 0.05 & 1.08 & 0.28 \\
\hline Physical activity & -0.09 & 0.05 & -1.79 & 0.07 \\
\hline Total testosterone LOG [ng/dl] & -0.21 & 0.05 & -3.79 & $<0.001$ \\
\hline \multicolumn{5}{|c|}{ Model 2: Dependent variable: total cholesterol LOG: $F(6,179)=9.77$, adj. $R^{2}=0.22, p<0.001$} \\
\hline S-Klotho LOG [pg/ml] & -0.02 & 0.07 & -0.29 & 0.77 \\
\hline Age [years] & 0.10 & 0.07 & 1.58 & 0.12 \\
\hline BMI ${ }^{1}\left[\mathrm{~kg} / \mathrm{m}^{2}\right]$ & 0.31 & 0.07 & $4, .22$ & $<0.001$ \\
\hline Alcohol use & 0.10 & 0.07 & 1.50 & 0.14 \\
\hline Physical activity & -0.24 & 0.07 & -3.60 & $<0.001$ \\
\hline Total testosterone LOG [ng/dl] & -0.08 & 0.07 & -1.04 & 0.30 \\
\hline \multicolumn{5}{|c|}{ Model 3 Dependent variable: Homocysteine LOG: $F(6,179)=0.80, a d j . ~ R^{2}<0.001, p=0.57$} \\
\hline S-Klotho LOG [pg/ml] & 0.05 & 0.08 & 0.63 & 0.53 \\
\hline Age [years] & 0.01 & 0.07 & 0.19 & 0.85 \\
\hline $\mathrm{BMI}^{1}\left[\mathrm{~kg} / \mathrm{m}^{2}\right]$ & 0.15 & 0.08 & 1.80 & 0.07 \\
\hline Alcohol use & 0.06 & 0.08 & 0.73 & 0.47 \\
\hline Physical activity & 0.01 & 0.07 & 0.13 & 0.90 \\
\hline Total testosterone LOG [ng/dl] & 0.06 & 0.08 & 0.67 & 0.50 \\
\hline
\end{tabular}


Model 4: Dependent variable: $h s C R P$ LOG: $F(6,179)=7.62$, adj. $R^{2}=0.18, p<0.001$

\begin{tabular}{|c|c|c|c|c|}
\hline S-Klotho LOG $[\mathrm{pg} / \mathrm{ml}]$ & -1.22 & 0.07 & -1.73 & 0.08 \\
\hline Age [years] & -0.01 & 0.07 & -0.10 & 0.92 \\
\hline $\mathrm{BMI}^{1}\left[\mathrm{~kg} / \mathrm{m}^{2}\right]$ & 0.43 & 0.08 & 5.62 & $<0.001$ \\
\hline Alcohol use & 0.03 & 0.07 & 0.48 & 0.63 \\
\hline Physical activity & -0.12 & 0.07 & -1.84 & 0.07 \\
\hline Total testosterone LOG [ng/dl] & 0.07 & 0.08 & 0.86 & 0.39 \\
\hline \multicolumn{5}{|c|}{ Model 5: Dependent variable: HbA1c: $F(6,179)=1.99$, adj. $R^{2}=0.03, p=0.07$} \\
\hline S-Klotho LOG [pg/ml] & -0.04 & 0.08 & -0.59 & 0.56 \\
\hline Age [years] & 0.14 & 0.07 & 1.89 & 0.06 \\
\hline $\mathrm{BMI}^{1}\left[\mathrm{~kg} / \mathrm{m}^{2}\right]$ & 0.01 & 0.08 & 0.07 & 0.94 \\
\hline Alcohol use & -0.13 & 0.08 & -1.75 & 0.08 \\
\hline Physical activity & -0.07 & 0.07 & -0.91 & 0.36 \\
\hline Total testosterone LOG [ng/dl] & -0.14 & 0.08 & -1.71 & 0.09 \\
\hline \multicolumn{5}{|c|}{ Model 6: Dependent variable: Glucose to insulin ratio LOG: $\mathbf{F}(\mathbf{6}, \mathbf{1 7 9})=\mathbf{1 8 . 2 4}$, adj. $\mathbf{R}^{2}=\mathbf{0 . 3 6}, p<0.001$} \\
\hline S-Klotho LOG [pg/ml] & -0.09 & 0.06 & -1.42 & 0.16 \\
\hline Age [years] & 0.02 & 0.06 & 0.44 & 0.66 \\
\hline $\operatorname{BMI}^{1}\left[\mathrm{~kg} / \mathrm{m}^{2}\right]$ & -0.44 & 0.07 & -6.59 & $<0.001$ \\
\hline Alcohol use & 0.01 & 0.06 & 0.23 & 0.82 \\
\hline Physical activity & 0.10 & 0.06 & 1.60 & 0.11 \\
\hline Total testosterone LOG [ng/dl] & 0.24 & 0.07 & 3.63 & $<0.001$ \\
\hline \multicolumn{5}{|c|}{ Model 7: Dependent variable: HOMA-IR LOG: $F(6,179)=19.99$, adj. $R^{2}=0.38, p<0.001$} \\
\hline S-Klotho LOG $[\mathrm{pg} / \mathrm{ml}]$ & 0.10 & 0.06 & 1.72 & 0.09 \\
\hline Age [years] & -0.01 & 0.06 & -0.14 & 0.89 \\
\hline BMI ${ }^{1}\left[\mathrm{~kg} / \mathrm{m}^{2}\right]$ & 0.47 & 0.07 & 7.08 & $<0.001$ \\
\hline Alcohol use & -0.03 & 0.06 & -0.56 & 0.57 \\
\hline Physical activity & -0.12 & 0.06 & -2.06 & 0.04 \\
\hline Total testosterone LOG [ng/dl] & -0.22 & $\mathbf{0 . 0 7}$ & -3.34 & 0.001 \\
\hline \multicolumn{5}{|c|}{ Model 8: Dependent variable: ALT/AST LOG: $\mathbf{F}(\mathbf{6}, \mathbf{1 7 9})=\mathbf{1 6 . 3 0}, \mathbf{a d j} . \mathbf{R}^{2}=\mathbf{0 . 3 3}, \boldsymbol{p}<\mathbf{0 . 0 0 1}$} \\
\hline S-Klotho LOG [pg/ml] & 0.13 & 0.06 & 1.98 & 0.04 \\
\hline Age [years] & 0.09 & 0.06 & 1.45 & 0.15 \\
\hline BMI ${ }^{1}\left[\mathrm{~kg} / \mathrm{m}^{2}\right]$ & -0.46 & 0.07 & -6.70 & $<0.001$ \\
\hline Alcohol use & 0.07 & 0.06 & 1.19 & 0.24 \\
\hline Physical activity & 0.14 & 0.06 & 2.27 & 0.02 \\
\hline Total testosterone LOG [ng/dl] & 0.16 & 0.07 & 2.26 & 0.02 \\
\hline
\end{tabular}

${ }^{1}$ BMI, Body Mass Index.

Table 4. The results of regression analysis of the relationship between s-Klotho and testosterone level, adjusted for age, BMI, alcohol use, and physical activity $\left(\mathrm{F}(5,180)=4.35\right.$, adj. $\left.R^{2}=0.08, p<0.001, N=186\right)$.

\begin{tabular}{lcccc}
\hline & $\boldsymbol{\beta}$ & SE $(\boldsymbol{\beta})$ & $\mathbf{t}(\mathbf{1 8 0})$ & $\boldsymbol{P}$ \\
\hline Age $[$ years] & 0.10 & 0.07 & 1.36 & 0.18 \\
$\mathrm{BMI}^{1}\left[\mathrm{~kg} / \mathrm{m}^{2}\right]$ & 0.11 & 0.08 & 1.39 & 0.17 \\
Alcohol use & $\mathbf{- 0 . 2 7}$ & $\mathbf{0 . 0 7}$ & $\mathbf{- 3 . 8 4}$ & $<\mathbf{0 . 0 0 1}$ \\
Total testosterone LOG $[\mathrm{ng} / \mathrm{dl}]$ & $\mathbf{0 . 1 7}$ & $\mathbf{0 . 0 8}$ & $\mathbf{2 . 1 3}$ & $\mathbf{0 . 0 3}$ \\
Physical activity & 0.03 & 0.07 & 0.47 & 0.64 \\
\hline
\end{tabular}

${ }^{1} \mathrm{BMI}$, Body Mass Index. 
testosterone increases Klotho gene expression and increased Klotho expression up-regulates the nuclear androgen receptor in mice [61]. Dote-Montero et al. [51] also showed a positive correlation between s-Klotho and testosterone level in healthy middle-aged sedentary adults (45-65 years old), suggesting that testosterone may up-regulate $\alpha$-Klotho gene expression via androgen receptor. Here we show that this relationship can also be observed in younger men (30-45 years old).

Although we did not find a significant relationship between s-Klotho and cardiometabolic risk markers levels it cannot be excluded that genetic polymorphisms of the klotho gene may be associated with these factors also in relatively young, healthy individuals, what would require further studies. Previous research showed that single nucleotide polymorphisms in the klotho gene are correlated with s-Klotho levels and the susceptibility to hypertension or coronary artery disease [2, 62, 63], cancer risk and longevity [64]. The results on a relationship between Klotho polymorphism and glucose homeostasis are not consistent [65, 66]. What is interesting, the relationship between Klotho polymorphism and aggravation of cardiometabolic disease is enhanced with age [34] what might confirm earlier presumption that s-Klotho level may be related with cardiometabolic risk only in middle-aged or older adults but not in relatively young individuals.

Interpreting these results requires an understanding of the limitations of the study. First, because of the cross-sectional design of the study no firm conclusions of causal association can be drawn from this study. Second, s-Klotho and cardiometabolic risk markers levels were assayed only once. Despite the rigorous study protocol we cannot exclude the possibility of some intra-individual variability in the measured markers, especially as little is known about intra-individual variation of s-Klotho (e.g. daily fluctuations, etc.). The design of the future studies should include repeated measurements of s-Klotho and cardiometabolic risk markers levels. Finally, it is possible that some discrepancies in the results of the studies on the relationship between s-Klotho level and other measures of health may be due to the differences in methods used for s-Klotho measurement [67]. Hiejboer et al. [67] evaluated the quality of the three commercially available s-Klotho assays and showed poor inter-assay as well as intra-assay agreement between them. IBL assay (used in this study) was the only one that provided information on the epitopes against which their antibodies are directed, offering the best results after evaluation of different tests including within-run variation, betweenrun variation, matrix effects, linearity, and recovery. However, as s-Klotho is relatively novel marker these differences should be factored in when comparing the results of various studies.

In conclusion, our study showed no relationship between s-Klotho and cardiometabolic risk markers level in healthy, non-smoking adults between 30 and 45 years. Nonetheless, future prospective studies should investigate the importance of s-Klotho measurements in cardiovascular risk stratification and its possible role as an early marker of the risk of developing cardiometabolic health.

\section{MATERIALS AND METHODS}

This cross-sectional study is part of a larger research project focused on men's health, conducted on 209 men $\left(\mathrm{M}_{\mathrm{age}}=35.26, \quad \mathrm{SD}_{\mathrm{age}}=3.49\right)$ from a western, urban population. Participants were recruited via information in local media or social networks. The study protocol and methodology were designed according to the Declaration of Helsinki (2013) and approved by local ethics committee. An informed written consent was obtained for participation in the study and use of data for scientific purposes from all participants.

\section{Participants}

The criteria for inclusion for this study were as follows: age between 30-45 years, no diagnosed chronic disease (diabetes, cardiovascular disease, autoimmunological, etc.), no hormonal treatment, not smoking, no ongoing infections. Current health status was assessed based on blood morphology with smear and C-reactive protein (CRP) level. From the initial group of participants, 24 were excluded from the analyses due to the following reasons: a) age below 30 years $(\mathrm{N}=2)$; b) elevated CRP level $(\mathrm{CRP}>10 \mu \mathrm{g} / \mathrm{ml})$, indicating ongoing inflammatory state $(\mathrm{N}=1)$; c) missing data $(\mathrm{N}=20)$. Renal function was evaluated based on eGFR and creatinine levels. All participants had eGFR value above 60 $\mathrm{ml} / \mathrm{min} / \mathrm{m} 2$ (the lowest value was $63.40 \mathrm{ml} / \mathrm{min} / \mathrm{m} 2$ ) and creatine within the clinical norm. Thus, the final analyses included 186 healthy men of age between 29.73 and 44.29 years $\left(\mathrm{M}_{\mathrm{age}}=35.33, \mathrm{SD}_{\mathrm{age}}=3.47\right)$.

\section{Procedures}

Fasting blood sample was taken between 7:30 a.m. and 9:00 a.m. for blood biochemical and hormone analyses. Participants were asked to refrain from physical activity, heavy meals and alcohol for 24 hours before the study visit. The participants completed questionnaire about demographic data, current and past health problems, medications, smoking and alcohol drinking pattern. Among the participants, 36 individuals declared that they had regularly smoked in the past (quitted at least 
one year prior the visit) and 150 stated that they had never smoked. Participants were also asked about the level of physical activity: the number and length (in minutes) of trainings per week and the type of sport practiced. The type of sport activities practiced by the participants were comparable in terms of intensity (running, biking, swimming, football, basketball, calisthenics, tennis, squash, CrossFit, strength workout). The participants were divided into two categories: 1) physically active $(\mathrm{N}=99)$, which included individuals who declared regular physical activity at least 60 mins/week; 2) and inactive ( $\mathrm{N}=87)$, which included participants with no regular sport activity. There were no professional sportsmen in the study sample. Participants were also asked how often they drink alcohol and based on their answers they were divided into three groups: 1) rarely - i.e. once per month or less often $(\mathrm{N}=49), 2)$ sometimes - i.e. 2-4 times per month $(\mathrm{N}=81), 3)$ often i.e. 2-3 times per week $(\mathrm{N}=56)$. Participants were also asked to estimate how stressful is their work and their personal life on scales from 1 (not stressful at all) to 7 (extremely stressful). The two scores were summarized resulting in self-perceived stress variable with the range from 2 to 14 .

\section{Anthropometry}

Height was measured twice with a classic stadiometer. The mean value of two measurements was used in the analysis. Weight was measured digitally (SECA mBCA 515) and BMI was calculated as $\mathrm{kg} / \mathrm{m}^{2}$. Additionally, fat and lean body mass were measured with bioimpedance analysis (SECA mBCA 515). Fat and lean mass indexes were calculated as fat mass and lean body mass in $\mathrm{kg}$ divided by height in meters ${ }^{2}$. Waist circumference was measured twice at the midpoint between the lower border of the rib cage and the iliac crest (c.a. at the level of the umbilicus) with a flexible tape. The mean of the two measurements was used in the analysis.

\section{Klotho and hormone measurements}

Blood samples were drawn after overnight fasting. After centrifugation serum was collected and stored at $-80^{\circ} \mathrm{C}$. Serum soluble circulating Klotho (s-Klotho) level was measured with enzyme-linked immunosorbent assay (ELISA) using commercial kits (IBL® Code no 27998; with inter-assay and intra-assay coefficient of variation less than $11.4 \%$ and less than $3,5 \%$ respectively with assay sensitivity of $6.15 \mathrm{pg} / \mathrm{ml}$ ), following the manufacturer's protocol. Calibrators (standards supplied with the kit) and serum samples were assayed in duplicate and the average absorbance value was used to calculate hormone concentration. Standard curve was created by plotting mean absorbance values for each standard ( $\mathrm{Y}$ axis) against its concentration ( $\mathrm{X}$ axis). Total s-Klotho concentration was calculated in relation to standard curve, multiplied by dilution ratio and expressed in $\mathrm{pg} / \mathrm{ml}$.

Quantitative measurement of total testosterone were assayed by certified analytical laboratory (DIAGNOSTYKA®) using Cobas analyzer and expressed in $\mathrm{ng} / \mathrm{dl}$.

\section{Cardiometabolic risk indices}

Morning blood pressure was measured in a sitting resting position with a digital sphygmomanometer and standard protocol. Readings were taken twice and the mean of the two measurements was calculated. Mean blood pressure (MBP) was calculated from mean systolic (SBP) and mean diastolic (DBP) blood pressure according to the formula: $\mathrm{MBP}=1 / 3(\mathrm{SBP}-\mathrm{DBP})+$ DBP.

Cardiometabolic risk score was calculated based on waist circumference, MBP, glucose, HDL-C and triglycerides levels, the clinical criteria for defining the risk of metabolic syndrome suggested by the International Diabetes Federation [68]. The values were standardized based on a formula: (value-mean)/standard deviation. To indicate greater cardiometabolic risk via increasing values, the standardized HDL-C values were multiplied by -1 . Cardiometabolic risk scores were calculated as arithmetic mean of these 5 standardized values and lower values indicate a better cardiometabolic risk profile. Additionally, cardiometabolic risk was estimated based on total cholesterol [69], homocysteine [70], and hsCRP levels [71].

Glucose, HDL-C, triglycerides and total cholesterol levels were assayed in serum in a certified laboratory (DIAGNOSTYKA) using spectrophotometry and Cobas analyzer. Homocysteine level was assayed in a certified laboratory (DIAGNOSTYKA) using turbidimetric method with Cobas analyzer. hsCRP level was assayed in the laboratory at Department of Human Biology (UWr) using enzyme-linked immunosorbent assay and ELISA kit (DEMEDITEC $®$ DE740011; inter- and intra-assay coefficient of variation were less than $6.3 \%$ and less than $6.9 \%$ respectively with assay sensitivity of $0.02 \mu \mathrm{g} / \mathrm{ml}$ ) in accordance to a user's manual. After series of incubation with conjugate solution and chromogen solution the reaction was stopped, and the absorbance value was read on ASYS UVM340 spectrophotometers with $\lambda=450 \mathrm{~nm}$. The standard curve was plotted with the average absorbance value (y axis) of each standards against its concentration (x axis). The participant's hsCRP levels were calculated in relation to standard curve and expressed in $\mu \mathrm{g} / \mathrm{ml}$. 
Insulin sensitivity was estimated based on glycated hemoglobin level [72], the homeostatic model assessment of insulin resistance index (HOMA-IR) [73], and fasting glucose to insulin level ratio. Fasting insulin level was measured in serum according to the procedure $\mathrm{IB} / \mathrm{LAB} / 100$ in a certified laboratory (DIAGNOSTYKA). Glycated hemoglobin (HbA1c) level was assayed in blood with HPLC method with Variant analyzer.

Liver function, related with cardiometabolic risk, was evaluated based on AST/ALT ratio [74]. ALT and AST levels were assayed in a certified laboratory (DIAGNOSTYKA).

Creatinine level was measured to control for renal functions. Creatinine level was assayed in a certified laboratory (DIAGNOSTYKA).

\section{Statistical analyses}

Based on the visual inspection of graphs, kurtosis and skewness values the distribution of levels of s-Klotho, triglycerides, total cholesterol, homocysteine, hsCRP, glucose, insulin, HOMA-IR, ALT, AST, creatinine, testosterone, glucose to insulin ratio, and ALT/AST ratio were assessed as non-normally distributed. Thus, these variables were log-transformed in order to obtain normal or near normal distribution.

T-test was used to verify if participants who smoked in the past $(\mathrm{N}=36)$ and participants who have never smoked $(\mathrm{N}=150)$ differed in terms of s-Klotho or cardiometabolic risk markers levels. T-test was also used to verify if participants who were classified as physically active $(\mathrm{N}=99)$ and participants who were classified as inactive $(\mathrm{N}=87)$ differed in terms of s-Klotho and cardiometabolic risk markers levels. ANOVA was used in order to verify if participants differed in terms of levels of s-Klotho and cardiometabolic risk markers levels depending on how often they drink alcohol: (1) rarely $(\mathrm{N}=49) ; 2)$ sometimes $(\mathrm{N}=81) ; 3)$ often $(\mathrm{N}=56)$. Tukey test was used as a post-hoc test. Pearson correlation was used in order to verify if s-Klotho level is related with controlled variables (chronological age, adiposity measures, testosterone and psychological stress level).

First, the relationship between s-Klotho and cardiometabolic risk markers levels was verified with Pearson correlation analysis. Then, a simple linear regression model was used to test the association between S-Klotho and cardiometabolic risk markers levels, adjusting for age, body composition, alcohol use, testosterone level and physical activity. Stress was not included as it was not related with any of the measures of cardiometabolic risk or s-Klotho level.

Analyses were performed with Statistica 12.0 software. The results were interpreted as statistically significant if $p<0.05$.

\section{AUTHOR CONTRIBUTIONS}

$\mathrm{A} \dot{Z}$ and $\mathrm{JN}$ conceived and designed the study, collected the data; A $\dot{Z}$ performed the analysis, wrote the paper; $\mathrm{JN}$ and BP critically reviewed the manuscript.

\section{CONFLICTS OF INTEREST}

The authors declare no conflicts of interest.

\section{FUNDING}

Narodowe Centrum Nauki, grant no 2017/27/B/NZ8/ 00500 .

\section{REFERENCES}

1. Kuro-o M, Matsumura $Y$, Aizawa H, Kawaguchi $H$, Suga T, Utsugi T, Ohyama Y, Kurabayashi M, Kaname T, Kume $\mathrm{E}$, Iwasaki $\mathrm{H}$, lida A, Shiraki-lida $\mathrm{T}$, et al. Mutation of the mouse klotho gene leads to a syndrome resembling ageing. Nature. 1997; 390:45-51.

https://doi.org/10.1038/36285

PMID: 9363890

2. Arking DE, Atzmon G, Arking A, Barzilai N, Dietz HC. Association between a functional variant of the KLOTHO gene and high-density lipoprotein cholesterol, blood pressure, stroke, and longevity. Circ Res. 2005; 96:412-8.

https://doi.org/10.1161/01.RES.0000157171.04054.30 PMID:15677572

3. Kuro-o M. Klotho. Pflugers Arch. 2010; 459:333-43. https://doi.org/10.1007/s00424-009-0722-7 PMID:19730882

4. Kurosu H, Yamamoto M, Clark JD, Pastor JV, Nandi A, Gurnani P, McGuinness OP, Chikuda H, Yamaguchi M, Kawaguchi H, Shimomura I, Takayama Y, Herz J, et al. Suppression of aging in mice by the hormone Klotho. Science. 2005; 309:1829-33. https://doi.org/10.1126/science.1112766 PMID: 16123266

5. Chang $Q$, Hoefs $S$, van $\operatorname{der}$ Kemp AW, Topala CN, Bindels RJ, Hoenderop JG. The beta-glucuronidase klotho hydrolyzes and activates the TRPV5 channel. Science. 2005; 310:490-3. https://doi.org/10.1126/science.1114245 PMID:16239475 
6. Cha SK, Ortega B, Kurosu H, Rosenblatt KP, Kuro-O M, Huang CL. Removal of sialic acid involving Klotho causes cell-surface retention of TRPV5 channel via binding to galectin-1. Proc Natl Acad Sci USA. 2008; 105:9805-10.

https://doi.org/10.1073/pnas.0803223105

PMID:18606998

7. Hu MC, Shi M, Zhang J, Pastor J, Nakatani T, Lanske B, Razzaque MS, Rosenblatt KP, Baum MG, Kuro-o M, Moe OW. Klotho: a novel phosphaturic substance acting as an autocrine enzyme in the renal proximal tubule. FASEB J. 2010; 24:3438-50.

https://doi.org/10.1096/fj.10-154765 PMID:20466874

8. Sopjani $M$, Alesutan I, Dërmaku-Sopjani $M, G u S$, Zelenak C, Munoz C, Velic A, Föller M, Rosenblatt KP, Kuro-o M, Lang F. Regulation of the $\mathrm{Na}+/ \mathrm{K}+$ ATPase by Klotho. FEBS Lett. 2011; 585:1759-64. https://doi.org/10.1016/i.febslet.2011.05.021 PMID:21605558

9. Drew DA, Katz R, Kritchevsky $S$, Ix J, Shlipak M, Gutiérrez OM, Newman A, Hoofnagle A, Fried L, Semba RD, Sarnak M. Association between Soluble Klotho and Change in Kidney Function: The Health Aging and Body Composition Study. J Am Soc Nephrol. 2017; 28:1859-66.

https://doi.org/10.1681/ASN.2016080828

PMID:28104822

10. Razzaque MS. The FGF23-Klotho axis: endocrine regulation of phosphate homeostasis. Nat Rev Endocrinol. 2009; 5:611-9.

https://doi.org/10.1038/nrendo.2009.196 PMID:19844248

11. Nie $F$, Wu D, Du $H$, Yang $X$, Yang $M$, Pang $X, X u$ Y. Serum klotho protein levels and their correlations with the progression of type 2 diabetes mellitus. J Diabetes Complications. 2017; 31:594-8.

https://doi.org/10.1016/j.jdiacomp.2016.11.008

PMID:27916483

12. Wolf I, Levanon-Cohen S, Bose S, Ligumsky H, Sredni B, Kanety H, Kuro-o M, Karlan B, Kaufman B, Koeffler HP, Rubinek T. Klotho: a tumor suppressor and a modulator of the IGF-1 and FGF pathways in human breast cancer. Oncogene. 2008; 27:7094-105. https://doi.org/10.1038/onc.2008.292 PMID:18762812

13. Christov M, Neyra JA, Gupta S, Leaf DE. Fibroblast Growth Factor 23 and Klotho in AKI. Semin Nephrol. 2019; 39:57-75.

https://doi.org/10.1016/i.semnephrol.2018.10.005 PMID:30606408

14. Yamamoto M, Clark JD, Pastor JV, Gurnani P, Nandi A, Kurosu H, Miyoshi M, Ogawa $\mathrm{Y}$, Castrillon DH, Rosenblatt KP, Kuro-o M. Regulation of oxidative stress by the anti-aging hormone klotho. J Biol Chem. 2005; 280:38029-34.

https://doi.org/10.1074/jbc.M509039200

PMID:16186101

15. Amaro-Gahete FJ, de-la-O A, Jurado-Fasoli L, Ruiz JR, Castillo MJ, Gutiérrez Á. Role of Exercise on S-Klotho Protein Regulation: A Systematic Review. Curr Aging Sci. 2018; 11:100-7. https://doi.org/10.2174/187460981166618070210133 8 PMID:29962352

16. Kuro-o M. Klotho in health and disease. Curr Opin Nephrol Hypertens. 2012; 21:362-8. https://doi.org/10.1097/MNH.0b013e32835422ad PMID:22660551

17. Baylis D, Bartlett DB, Patel HP, Roberts HC. Understanding how we age: insights into inflammaging. Longev Healthspan. 2013; 2:8.

https://doi.org/10.1186/2046-2395-2-8 PMID:24472098

18. Cerami A. Hypothesis. Glucose as a mediator of aging. J Am Geriatr Soc. 1985; 33:626-34. https://doi.org/10.1111/i.1532-5415.1985.tb06319.x PMID: 3897348

19. Liguori I, Russo G, Curcio F, Bulli G, Aran L, Della-Morte D, Gargiulo G, Testa G, Cacciatore F, Bonaduce D, Abete P. Oxidative stress, aging, and diseases. Clin Interv Aging. 2018; 13:757-72. https://doi.org/10.2147/CIA.S158513 PMID:29731617

20. Holzenberger M, Kappeler L, De Magalhaes Filho C. IGF-1 signaling and aging. Exp Gerontol. 2004; 39:1761-4.

https://doi.org/10.1016/j.exger.2004.08.017 PMID:15582293

21. Ohnishi M, Razzaque MS. Dietary and genetic evidence for phosphate toxicity accelerating mammalian aging. FASEB J. 2010; 24:3562-71. https://doi.org/10.1096/fj.09-152488 PMID:20418498

22. Koyama D, Sato $Y$, Aizawa M, Maki T, Kurosawa $M$, Kuro-o M, Furukawa Y. Soluble $\alpha$ Klotho as a candidate for the biomarker of aging. Biochem Biophys Res Commun. 2015; 467:1019-25.

https://doi.org/10.1016/i.bbrc.2015.10.018 PMID:26462468

23. Guariguata L, Whiting DR, Hambleton I, Beagley J, Linnenkamp U, Shaw JE. Global estimates of diabetes prevalence for 2013 and projections for 2035. Diabetes Res Clin Pract. 2014; 103:137-49. https://doi.org/10.1016/j.diabres.2013.11.002 PMID:24630390

24. Lopez-Candales A, Hernández Burgos PM, HernandezSuarez DF, Harris D. Linking Chronic Inflammation with 
Cardiovascular Disease: From Normal Aging to the Metabolic Syndrome. J Nat Sci. 2017; 3:e341.

PMID:28670620

25. Veronica G, Esther RR. Aging, metabolic syndrome and the heart. Aging Dis. 2012; 3:269-79.

PMID:22724085

26. Semba RD, Cappola AR, Sun K, Bandinelli S, Dalal M, Crasto C, Guralnik JM, Ferrucci L. Plasma klotho and cardiovascular disease in adults. J Am Geriatr Soc. 2011; 59:1596-601.

https://doi.org/10.1111/i.1532-5415.2011.03558.x PMID:21883107

27. Pan HC, Chou KM, Lee CC, Yang NI, Sun CY. Circulating Klotho levels can predict long-term macrovascular outcomes in type 2 diabetic patients. Atherosclerosis. 2018; 276:83-90.

https://doi.org/10.1016/i.atherosclerosis.2018.07.006 PMID:30048945

28. Ding HY, Ma HX. Significant roles of anti-aging protein klotho and fibroblast growth factor23 in cardiovascular disease. J Geriatr Cardiol. 2015; 12:439-47.

https://doi.org/10.11909/j.issn.1671-

5411.2015.04.017 PMID:26347327

29. Kusaba T, Okigaki M, Matui A, Murakami M, Ishikawa K, Kimura T, Sonomura K, Adachi $Y$, Shibuya M, Shirayama T, Tanda S, Hatta T, Sasaki S, et al. Klotho is associated with VEGF receptor-2 and the transient receptor potential canonical-1 $\mathrm{Ca} 2+$ channel to maintain endothelial integrity. Proc Natl Acad Sci USA. 2010; 107:19308-13.

https://doi.org/10.1073/pnas.1008544107

PMID:20966350

30. Lau WL, Leaf EM, Hu MC, Takeno MM, Kuro-o M, Moe OW, Giachelli CM. Vitamin D receptor agonists increase klotho and osteopontin while decreasing aortic calcification in mice with chronic kidney disease fed a high phosphate diet. Kidney Int. 2012; 82:1261-70.

https://doi.org/10.1038/ki.2012.322 PMID:22932118

31. Navarro-González JF, Donate-Correa J, Muros de Fuentes $M$, Pérez-Hernández $H$, Martínez-Sanz $R$, Mora-Fernández C. Reduced Klotho is associated with the presence and severity of coronary artery disease. Heart. 2014; 100:34-40.

https://doi.org/10.1136/heartinl-2013-304746 PMID:24165855

32. Xie J, Cha SK, An SW, Kuro-O M, Birnbaumer L, Huang CL. Cardioprotection by Klotho through downregulation of TRPC6 channels in the mouse heart. Nat Commun. 2012; 3:1238. https://doi.org/10.1038/ncomms2240 PMID:23212367
33. Liang $W Y$, Wang $L H$, Wei JH, Li QL, Li QY, Liang $Q$, Hu $\mathrm{NQ}$, Li LH. No significant association of serum klotho concentration with blood pressure and pulse wave velocity in a Chinese population. Sci Rep. 2021; $11: 2374$.

https://doi.org/10.1038/s41598-021-82258-5

PMID:33504927

34. Rhee EJ, Oh KW, Lee WY, Kim SY, Jung CH, Kim BJ, Sung KC, Kim BS, Kang JH, Lee MH, Kim SW, Park JR. The differential effects of age on the association of KLOTHO gene polymorphisms with coronary artery disease. Metabolism. 2006; 55:1344-51.

https://doi.org/10.1016/i.metabol.2006.05.020 PMID:16979405

35. Amaro-Gahete FJ, Jurado-Fasoli L, Sanchez-Delgado G, García-Lario JV, Castillo MJ, Ruiz JR. Relationship between plasma S-Klotho and cardiometabolic risk in sedentary adults. Aging (Albany NY). 2020; 12:2698-710.

https://doi.org/10.18632/aging.102771

PMID:31958773

36. Keles N, Caliskan M, Dogan B, Keles NN, Kalcik M, Aksu F, Kostek O, Aung SM, Isbilen B, Oguz A. Low Serum Level of Klotho Is an Early Predictor of Atherosclerosis. Tohoku J Exp Med. 2015; 237:17-23. https://doi.org/10.1620/tjem.237.17 PMID:26289053

37. Nakanishi K, Nishida M, Taneike M, Yamamoto R, Moriyama T, Yamauchi-Takihara K. Serum Klotho Levels Contribute to the Prevention of Disease Progression. Int J Gen Med. 2021; 14:229-36. https://doi.org/10.2147/IJGM.S291437 PMID:33519229

38. Tominaga K, Olgun A, Smith JR, Pereira-Smith OM. Genetics of cellular senescence. Mech Ageing Dev. 2002; 123:927-36. https://doi.org/10.1016/s0047-6374(02)00030-1 PMID: 12044941

39. Fulop T, Larbi A, Witkowski JM, McElhaney J, Loeb M, Mitnitski A, Pawelec G. Aging, frailty and age-related diseases. Biogerontology. 2010; 11:547-63. https://doi.org/10.1007/s10522-010-9287-2 PMID:20559726

40. Centers for Disease Control and Prevention (CDC). Division of Health Interview Statistics, data from the National Health Interview Survey. Data Computed by Personnel in the Division of Diabetes Translation, National Center for Chronic Disease Prevention and Health Promotion. 2010.

41. Koopman RJ, Mainous AG 3rd, Diaz VA, Geesey ME. Changes in age at diagnosis of type 2 diabetes mellitus in the United States, 1988 to 2000. Ann Fam Med. 2005; 3:60-3. 
https://doi.org/10.1370/afm.214

PMID:15671192

42. Florez JC, Sjögren M, Agapakis CM, Burtt NP, Almgren P, Lindblad U, Berglund G, Tuomi T, Gaudet D, Daly MJ, Ardlie KG, Hirschhorn JN, Altshuler D, Groop L. Association testing of common variants in the insulin receptor substrate-1 gene (IRS1) with type 2 diabetes. Diabetologia. 2007; 50:1209-17.

https://doi.org/10.1007/s00125-007-0657-5

PMID:17443311

43. Laakso M, Pyörälä K. Age of onset and type of diabetes. Diabetes Care. 1985; 8:114-7.

https://doi.org/10.2337/diacare.8.2.114 PMID:3873328

44. Harris MI, Klein R, Welborn TA, Knuiman MW. Onset of NIDDM occurs at least 4-7 yr before clinical diagnosis. Diabetes Care. 1992; 15:815-9.

https://doi.org/10.2337/diacare.15.7.815

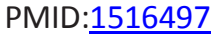

45. Zuo Z, Lei H, Wang X, Wang Y, Sonntag W, Sun Z. Agingrelated kidney damage is associated with a decrease in klotho expression and an increase in superoxide production. Age (Dordr). 2011; 33:261-74.

https://doi.org/10.1007/s11357-010-9176-2

PMID:20830528

46. Kim JH, Hwang KH, Park KS, Kong ID, Cha SK. Biological Role of Anti-aging Protein Klotho. J Lifestyle Med. 2015; 5:1-6.

https://doi.org/10.15280/jlm.2015.5.1.1

PMID:26528423

47. Avin KG, Coen PM, Huang W, Stolz DB, Sowa GA, Dubé JJ, Goodpaster BH, O’Doherty RM, Ambrosio F. Skeletal muscle as a regulator of the longevity protein, Klotho. Front Physiol. 2014; 5:189.

https://doi.org/10.3389/fphys.2014.00189

PMID:24987372

48. Amaro-Gahete FJ, de-la-O A, Jurado-Fasoli L, Gutiérrez Á, Ruiz JR, Castillo MJ. Association of physical activity and fitness with S-Klotho plasma levels in middle-aged sedentary adults: The FIT-AGEING study. Maturitas. 2019; 123:25-31.

https://doi.org/10.1016/j.maturitas.2019.02.001 PMID:31027673

49. Brand JS, van der Tweel I, Grobbee DE, Emmelot-Vonk $\mathrm{MH}$, van der Schouw YT. Testosterone, sex hormonebinding globulin and the metabolic syndrome: a systematic review and meta-analysis of observational studies. Int J Epidemiol. 2011; 40:189-207.

https://doi.org/10.1093/ije/dyq158

PMID:20870782

50. Corona G, Rastrelli G, Di Pasquale G, Sforza A, Mannucci E, Maggi M. Testosterone and
Cardiovascular Risk: Meta-Analysis of Interventional Studies. J Sex Med. 2018; 15:820-38.

https://doi.org/10.1016/j.jsxm.2018.04.641

PMID:29803351

51. Dote-Montero M, Amaro-Gahete FJ, De-la-O A, JuradoFasoli L, Gutierrez A, Castillo MJ. Study of the association of DHEAS, testosterone and cortisol with SKlotho plasma levels in healthy sedentary middle-aged adults. Exp Gerontol. 2019; 121:55-61.

https://doi.org/10.1016/i.exger.2019.03.010 PMID:30928678

52. Jurado-Fasoli L, Amaro-Gahete FJ, De-la-O A, Gutiérrez Á, Castillo MJ. Alcohol consumption and S-Klotho plasma levels in sedentary healthy middle-aged adults: A cross sectional study. Drug Alcohol Depend. 2019; 194:107-11.

https://doi.org/10.1016/j.drugalcdep.2018.09.024 PMID:30419404

53. Prather AA, Epel ES, Arenander J, Broestl L, Garay BI, Wang D, Dubal DB. Longevity factor klotho and chronic psychological stress. Transl Psychiatry. 2015; 5:e585. https://doi.org/10.1038/tp.2015.81 PMID:26080320

54. Semba RD, Cappola AR, Sun K, Bandinelli S, Dalal M, Crasto C, Guralnik JM, Ferrucci L. Plasma klotho and mortality risk in older community-dwelling adults. J Gerontol A Biol Sci Med Sci. 2011; 66:794-800.

https://doi.org/10.1093/gerona/glr058

PMID:21474560

55. Su XM, Yang W. Klotho protein lowered in elderly hypertension. Int J Clin Exp Med. 2014; 7:2347-50.

PMID:25232434

56. Brandenburg VM, Kleber ME, Vervloet MG, Larsson TE, Tomaschitz A, Pilz S, Stojakovic T, Delgado G, Grammer TB, Marx N, März W, Scharnagl H. Soluble klotho and mortality: the Ludwigshafen Risk and Cardiovascular Health Study. Atherosclerosis. 2015; 242:483-9.

https://doi.org/10.1016/i.atherosclerosis.2015.08.017 PMID:26298739

57. Martín-Núñez E, Donate-Correa J, Muros-de-Fuentes M, Mora-Fernández C, Navarro-González JF. Implications of Klotho in vascular health and disease. World J Cardiol. 2014; 6:1262-9. https://doi.org/10.4330/wjc.v6.i12.1262 PMID:25548616

58. Feldman $H A$, Longcope $C$, Derby $C A$, Johannes $C B$, Araujo AB, Coviello AD, Bremner WJ, McKinlay JB. Age trends in the level of serum testosterone and other hormones in middle-aged men: longitudinal results from the Massachusetts male aging study. J Clin Endocrinol Metab. 2002; 87:589-98. https://doi.org/10.1210/jcem.87.2.8201 PMID:11836290 
59. Shores MM, Matsumoto AM. Testosterone, aging and survival: biomarker or deficiency. Curr Opin Endocrinol Diabetes Obes. 2014; 21:209-16. https://doi.org/10.1097/MED.0000000000000057 PMID:24722173

60. Yeap BB, Araujo AB, Wittert GA. Do low testosterone levels contribute to ill-health during male ageing? Crit Rev Clin Lab Sci. 2012; 49:168-82. https://doi.org/10.3109/10408363.2012.725461 PMID:23094995

61. Hsu SC, Huang SM, Lin SH, Ka SM, Chen A, Shih MF, Hsu YJ. Testosterone increases renal anti-aging klotho gene expression via the androgen receptor-mediated pathway. Biochem J. 2014; 464:221-9. https://doi.org/10.1042/BJ20140739 PMID:25163025

62. Akbari H, Asadikaram G, Aria H, Fooladi S, Vakili S, Masoumi M. Association of Klotho gene polymorphism with hypertension and coronary artery disease in an Iranian population. BMC Cardiovasc Disord. 2018; 18:237.

https://doi.org/10.1186/s12872-018-0971-5 PMID: 30547758

63. Arking $D E$, Becker $D M$, Yanek $L R$, Fallin $D$, Judge $D P$, Moy TF, Becker LC, Dietz HC. KLOTHO allele status and the risk of early-onset occult coronary artery disease. Am J Hum Genet. 2003; 72:1154-61. https://doi.org/10.1086/375035 PMID:12669274

64. Zhu Z, Xia W, Cui Y, Zeng F, Li Y, Yang Z, Hequn C. Klotho gene polymorphisms are associated with healthy aging and longevity: Evidence from a metaanalysis. Mech Ageing Dev. 2019; 178:33-40.

https://doi.org/10.1016/i.mad.2018.12.003 PMID: $\underline{0633899}$

65. Freathy RM, Weedon MN, Melzer D, Shields B, Hitman GA, Walker M, McCarthy MI, Hattersley AT, Frayling TM. The functional "KL-VS" variant of KLOTHO is not associated with type 2 diabetes in 5028 UK Caucasians. BMC Med Genet. 2006; 7:51. https://doi.org/10.1186/1471-2350-7-51 PMID:16753056

66. Rhee EJ, Oh KW, Yun EJ, Jung CH, Lee WY, Kim SW, Baek KH, Kang MI, Park SW. Relationship between polymorphisms G395A in promoter and C1818T in exon 4 of the KLOTHO gene with glucose metabolism and cardiovascular risk factors in Korean women. J Endocrinol Invest. 2006; 29:613-8. https://doi.org/10.1007/BF03344160 PMID:16957409
67. Heijboer AC, Blankenstein MA, Hoenderop J, de Borst $\mathrm{MH}$, Vervloet MG, and NIGRAM consortium. Laboratory aspects of circulating $\alpha$-Klotho. Nephrol Dial Transplant. 2013; 28:2283-7. https://doi.org/10.1093/ndt/gft236 PMID:23787542

68. Carracher AM, Marathe PH, Close KL. International Diabetes Federation 2017. J Diabetes. 2018; 10:353-6. https://doi.org/10.1111/1753-0407.12644 PMID:29345068

69. Vanuzzo D, Pilotto L, Mirolo R, Pirelli S. [Cardiovascular risk and cardiometabolic risk: an epidemiological evaluation]. G Ital Cardiol (Rome). 2008; 9:6S-17S. PMID:18773746

70. Sypniewska G. Laboratory assessment of cardiometabolic risk in overweight and obese children. Clin Biochem. 2015; 48:370-6. https://doi.org/10.1016/i.clinbiochem.2014.12.024 PMID:25583095

71. Lund MA, Thostrup AH, Frithioff-Bøjsøe C, LaustenThomsen U, Hedley PL, Pedersen O, Christiansen M, Hansen T, Holm JC. Low-grade inflammation independently associates with cardiometabolic risk in children with overweight/obesity. Nutr Metab Cardiovasc Dis. 2020; 30:1544-53. https://doi.org/10.1016/j.numecd.2020.04.024 PMID:32571613

72. Khaw KT, Wareham N. Glycated hemoglobin as a marker of cardiovascular risk. Curr Opin Lipidol. 2006; 17:637-43. https://doi.org/10.1097/MOL.0b013e3280106b95 PMID: 17095908

73. Ascaso JF, Romero P, Real JT, Priego A, Valdecabres C, Carmena R. [Insulin resistance quantification by fasting insulin plasma values and HOMA index in a non-diabetic population]. Med Clin (Barc). 2001; 117:530-3.

https://doi.org/10.1016/s0025-7753(01)72168-9 PMID:11707218

74. Liu H, Zha X, Ding C, Hu L, Li M, Yu Y, Zhou W, Wang T, Zhu L, Bao H, Cheng X. AST/ALT Ratio and Peripheral Artery Disease in a Chinese Hypertensive Population: A Cross-Sectional Study. Angiology. 2021; 72:916-22. https://doi.org/10.1177/00033197211004410 PMID:33779311 


\section{SUPPLEMENTARY MATERIALS}

\section{Supplementary Tables}

Supplementary Table 1. Descriptive statistics of additional variables ( $\mathrm{N}=186)$.

\begin{tabular}{lcccc}
\hline & M & SD & Min & Max \\
\hline MBP $^{1}[\mathrm{~mm} \mathrm{Hg}]$ & 93.13 & 9.75 & 67.83 & 119.67 \\
Triglycerides $[\mathrm{mg} / \mathrm{dl}]$ & 121.62 & 80.75 & 37.00 & 668.00 \\
Lean mass index $\left[\mathrm{kg} / \mathrm{m}^{2}\right]$ & 19.61 & 1.64 & 14.95 & 24.44 \\
Fat mass index $\left[\mathrm{kg} / \mathrm{m}^{2}\right]$ & 6.05 & 2.48 & 1.43 & 15.86 \\
Waist circumference $[\mathrm{cm}]$ & 92.00 & 10.29 & 69.50 & 129.00 \\
$\mathrm{HDL}^{2}[\mathrm{mg} / \mathrm{dl}]$ & 53.62 & 11.97 & 29.00 & 88.00 \\
Glucose $[\mathrm{mg} / \mathrm{dl}]_{\text {Insulin }[\mu \mathrm{IU} / \mathrm{ml}]}^{9.13}$ & 4.68 & 2.20 & 26.30 \\
$\mathrm{ALT}^{3}[\mathrm{U} / \mathrm{l}]$ & 92.30 & 8.00 & 71.90 & 122.70 \\
$\left.\mathrm{AST}^{\mathrm{U}} / \mathrm{U}\right]$ & 27.31 & 16.68 & 8.00 & 120.00 \\
\hline
\end{tabular}

${ }^{1} \mathrm{MBP}$, Mean blood pressure.

${ }^{2} \mathrm{HDL}$, High density protein.

${ }^{3} \mathrm{ALT}$, Alanine transaminase.

${ }^{4}$ AST, Aspartate aminotransferase. 
Supplementary Table 2. The difference in mean values of levels of $s$-Klotho, markers of cardiometabolic risk and controlled variables between men who had smoked in the past $(\mathrm{N}=36)$ and men who have never smoked $(\mathrm{N}=150)$.

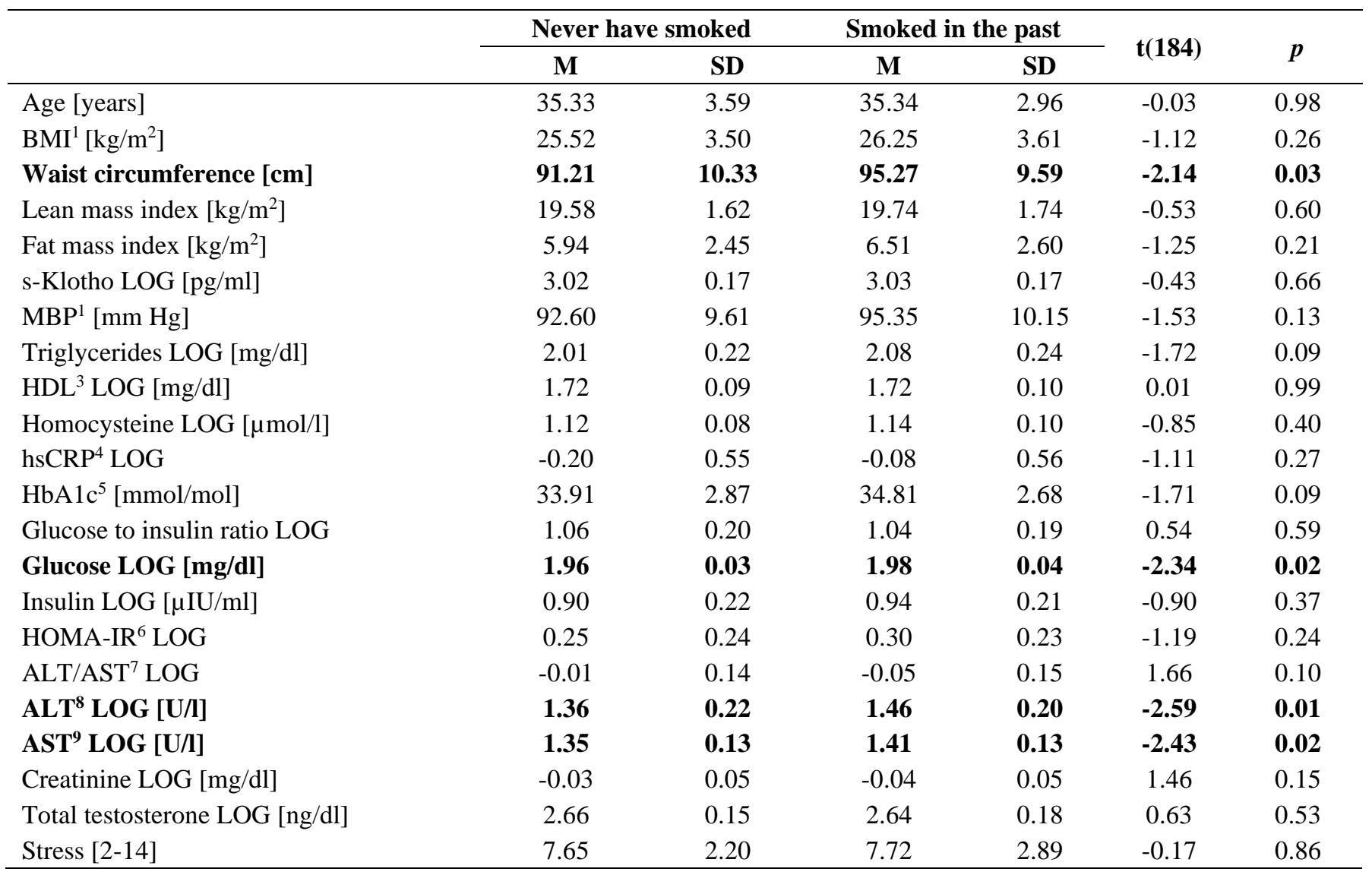

${ }^{1} \mathrm{BMI}$, Body mass index.

${ }^{2} \mathrm{MBP}$, Mean blood pressure.

${ }^{3} \mathrm{HDL}$, High density lipoprotein.

${ }^{4}$ hsCRP, High sensitivity C-reactive protein.

${ }^{5} \mathrm{HbA} 1 \mathrm{c}$, Glycated hemoglobin.

${ }^{6} \mathrm{HOMA}-\mathrm{IR}$, Homeostatic model assessment for insulin resistance.

${ }^{7}$ Aspartate aminotransferase (AST) to alanine transaminase (ALT) ratio.

${ }^{8} \mathrm{ALT}$, Alanine transaminase.

${ }^{9}$ AST, Aspartate aminotransferase. 
Supplementary Table 3. The difference in mean values of levels of $s$-Klotho, markers of cardiometabolic risk and controlled variables between physically active $(\mathrm{N}=99)$ and non-active men ( $N=87)$.

\begin{tabular}{|c|c|c|c|c|c|c|}
\hline & \multicolumn{2}{|c|}{ Physically active } & \multicolumn{2}{|c|}{ Non-active } & \multirow{2}{*}{$\mathbf{t}(\mathbf{1 8 4})$} & \multirow{2}{*}{$p$} \\
\hline & $\mathbf{M}$ & SD & $\mathbf{M}$ & SD & & \\
\hline Age [years] & 35.22 & 3.75 & 35.45 & 3.15 & -0.43 & 0.66 \\
\hline BMI $\left[\mathrm{kg} / \mathrm{m}^{2}\right]$ & 25.31 & 3.16 & 26.06 & 3.87 & -1.46 & 0.15 \\
\hline Waist circumference [cm] & 90.29 & 9.56 & 93.94 & 10.80 & -2.44 & 0.02 \\
\hline Lean mass index $\left[\mathrm{kg} / \mathrm{m}^{2}\right]$ & 19.70 & 1.56 & 19.51 & 1.73 & 0.81 & 0.42 \\
\hline Fat mass index $\left[\mathrm{kg} / \mathrm{m}^{2}\right]$ & 5.61 & 2.26 & 6.56 & 2.63 & -2.64 & 0.009 \\
\hline s-Klotho LOG [pg/ml] & 3.03 & 0.18 & 3.01 & 0.15 & 0.68 & 0.50 \\
\hline Cardiometabolic risk score & -0.12 & 0.63 & 0.15 & 0.74 & -2.68 & 0.008 \\
\hline $\mathrm{MBP}^{1}[\mathrm{~mm} \mathrm{Hg}]$ & 92.88 & 9.98 & 93.42 & 9.53 & -0.37 & 0.71 \\
\hline Triglycerides LOG [mg/dl] & 1.98 & 0.21 & 2.06 & 0.24 & -2.40 & 0.02 \\
\hline Total cholesterol LOG [mg/dl] & 2.26 & 0.08 & 2.30 & 0.08 & -4.11 & $<0.001$ \\
\hline $\mathrm{HDL}^{2} \mathrm{LOG}[\mathrm{mg} / \mathrm{dl}]$ & 1.73 & 0.09 & 1.70 & 0.10 & 1.89 & 0.06 \\
\hline Homocysteine LOG $[\mu \mathrm{mol} / 1]$ & 1.13 & 0.08 & 1.12 & 0.09 & 0.09 & 0.93 \\
\hline hsCRP ${ }^{3}$ LOG & -0.26 & 0.56 & -0.08 & 0.54 & -2.26 & 0.02 \\
\hline $\mathrm{HbA} 1 \mathrm{c}^{4}[\mathrm{mmol} / \mathrm{mol}]$ & 33.81 & 2.66 & 34.39 & 3.05 & -1.39 & 0.16 \\
\hline Glucose to insulin ratio LOG & 1.09 & 0.21 & 1.02 & 0.19 & 2.56 & 0.01 \\
\hline Glucose LOG [mg/dl] & 1.96 & $\mathbf{0 . 0 3}$ & 1.97 & 0.04 & -2.26 & 0.02 \\
\hline Insulin LOG $[\mu \mathrm{IU} / \mathrm{ml}]$ & 0.87 & 0.22 & 0.95 & 0.20 & -2.77 & 0.006 \\
\hline HOMA-IR ${ }^{5}$ LOG & 0.22 & 0.24 & 0.32 & 0.22 & -2.90 & 0.004 \\
\hline ALT/AST ${ }^{6}$ LOG & 0.01 & 0.14 & -0.05 & 0.14 & 3.08 & 0.002 \\
\hline $\mathbf{A L T}^{7} \mathbf{L O G}[\mathbf{U} / \mathbf{I}]$ & 1.34 & 0.19 & 1.42 & 0.24 & -2.42 & 0.02 \\
\hline $\mathrm{AST}^{8} \mathrm{LOG}[\mathrm{U} / \mathrm{l}]$ & 1.35 & 0.13 & 1.36 & 0.13 & -0.66 & 0.51 \\
\hline Creatinine LOG [mg/dl] & -0.02 & 0.05 & -0.04 & 0.05 & 1.86 & 0.06 \\
\hline Total testosterone LOG [ng/dl] & 2.69 & 0.14 & 2.63 & 0.17 & 2.64 & 0.009 \\
\hline Stress [2-14] & 7.64 & 2.26 & 7.69 & 2.46 & -0.15 & 0.88 \\
\hline
\end{tabular}

${ }^{1} \mathrm{MBP}$, Mean blood pressure.

${ }^{2} \mathrm{HDL}$, High density lipoprotein.

${ }^{3}$ hsCRP, High sensitivity C-reactive protein.

${ }^{4} \mathrm{HbA1c}$, Glycated hemoglobin.

${ }^{5} \mathrm{HOMA}-\mathrm{IR}$, Homeostatic model assessment for insulin resistance.

${ }^{6}$ Aspartate aminotransferase (AST) to alanine transaminase (ALT) ratio.

${ }^{7} \mathrm{ALT}$, Alanine transaminase.

${ }^{8} \mathrm{AST}$, Aspartate aminotransferase. 
Supplementary Table 4. The results of ANOVA for the difference in terms of the level of s-Klotho, cardiometabolic risk factors, and controlled variables between men who rarely drink alcohol (group 1: $N=49$ ), sometimes (group 2: $\mathrm{N}=81$ ), and men who often drink alcohol (group 3: $\mathrm{N}=56$ ).

\begin{tabular}{|c|c|c|c|c|}
\hline & Model & G1(Never) & G2(Sometimes) & G3(Often) \\
\hline Age [years] & $\mathrm{F}(2,183)=2.80, p=0.06$ & ns & $\mathrm{ns}$ & ns \\
\hline $\mathrm{BMI}^{3}\left[\mathrm{~kg} / \mathrm{m}^{2}\right]$ & $\mathrm{F}(2,183)=0.78, p=0.46$ & ns & $\mathrm{ns}$ & $\mathrm{ns}$ \\
\hline Waist circumference $[\mathrm{cm}]$ & $\mathrm{F}(2,183)=1.46, p=0.23$ & $\mathrm{~ns}$ & $\mathrm{~ns}$ & $\mathrm{~ns}$ \\
\hline Lean mass index $\left[\mathrm{kg} / \mathrm{m}^{2}\right]$ & $\mathrm{F}(2,183)=0.21, p=0.81$ & $\mathrm{~ns}$ & $\mathrm{~ns}$ & ns \\
\hline Fat mass index $\left[\mathrm{kg} / \mathrm{m}^{2}\right]$ & $\mathrm{F}(2,183)=0.91, p=0.40$ & $\mathrm{~ns}$ & $\mathrm{~ns}$ & $\mathrm{~ns}$ \\
\hline s-Klotho LOG [pg/ml] & $F(2,183)=6.90, p=0.001^{1}$ & $3.09 \pm 0.17$ & $3.02 \pm 0.16$ & $2.97 \pm 0.16$ \\
\hline Cardiometabolic risk score & $\mathrm{F}(2,183)=1.41, p=0.25$ & ns & $\mathrm{ns}$ & ns \\
\hline $\mathrm{MBP}^{4}[\mathrm{~mm} \mathrm{Hg}]$ & $\mathrm{F}(2,183)=1.88, p=0.16$ & $\mathrm{~ns}$ & $\mathrm{~ns}$ & $\mathrm{~ns}$ \\
\hline Triglycerides LOG [mg/dl] & $\mathrm{F}(2,183)=4.21, p=0.02^{2}$ & $1.94 \pm 0.17$ & $2.03 \pm 0.23$ & $2.06 \pm 0.24$ \\
\hline Total cholesterol LOG [mg/dl] & $\mathrm{F}(2,183)=2.00, p=0.14$ & $\mathrm{~ns}$ & $\mathrm{~ns}$ & ns \\
\hline $\mathrm{HDL}^{5} \mathrm{LOG}[\mathrm{mg} / \mathrm{dl}]$ & $\mathrm{F}(2,183)=0.24, p=0.78$ & $\mathrm{~ns}$ & $\mathrm{~ns}$ & $\mathrm{~ns}$ \\
\hline Homocysteine LOG $[\mu \mathrm{mol} / 1]$ & $\mathrm{F}(2,183)=0.70, p=0.50$ & ns & $\mathrm{ns}$ & ns \\
\hline hsCRP ${ }^{6}$ LOG & $\mathrm{F}(2,183)=0.97, p=0.38$ & ns & ns & ns \\
\hline $\mathrm{HbA} 1 \mathrm{c}^{7}[\mathrm{mmol} / \mathrm{mol}]$ & $\mathrm{F}(2,183)=1.44, p=0.24$ & ns & $\mathrm{ns}$ & ns \\
\hline Glucose to insulin ratio LOG & $\mathrm{F}(2,183)=0.22, p=0.80$ & $\mathrm{~ns}$ & $\mathrm{~ns}$ & ns \\
\hline Glucose LOG [mg/dl] & $\mathrm{F}(2,183)=0.40, p=0.67$ & ns & $\mathrm{ns}$ & $\mathrm{ns}$ \\
\hline Insulin LOG $[\mu \mathrm{IU} / \mathrm{ml}]$ & $\mathrm{F}(2,183)=0.22, p=0.80$ & ns & $\mathrm{ns}$ & $\mathrm{ns}$ \\
\hline HOMA-IR ${ }^{8}$ LOG & $\mathrm{F}(2,183)=0.22, p=0.80$ & $\mathrm{~ns}$ & $\mathrm{~ns}$ & $\mathrm{~ns}$ \\
\hline ALT/AST ${ }^{9}$ LOG & $\mathrm{F}(2,183)=0.01, p=0.99$ & $\mathrm{~ns}$ & $\mathrm{~ns}$ & ns \\
\hline $\mathrm{ALT}^{10} \mathrm{LOG}[\mathrm{U} / \mathrm{l}]$ & $\mathrm{F}(2,183)=0.91, p=0.40$ & ns & $\mathrm{ns}$ & ns \\
\hline $\mathrm{AST}^{11} \mathrm{LOG}[\mathrm{U} / \mathrm{l}]$ & $\mathrm{F}(2,183)=2.53, p=0.08$ & ns & $\mathrm{ns}$ & $\mathrm{ns}$ \\
\hline Creatinine LOG [mg/dl] & $\mathrm{F}(2,183)=1.37, p=0.26$ & ns & ns & ns \\
\hline Total testosterone LOG $[\mathrm{ng} / \mathrm{dl}]$ & $\mathrm{F}(2,183)=0.51, p=0.60$ & ns & $\mathrm{ns}$ & $\mathrm{ns}$ \\
\hline Stress [2-14] & $\mathrm{F}(2,183)=0.82, p=0.44$ & $\mathrm{~ns}$ & $\mathrm{~ns}$ & $\mathrm{~ns}$ \\
\hline
\end{tabular}

${ }^{1}$ The difference between $G 1$ and $G 2$ was significant $(p=0.04)$; The difference between $G 1$ and $G 3$ was significant $(p<0.001)$. The difference between $G 2$ and $G 3$ is not significant $(p=0.25)$.

${ }^{2}$ The difference between $G 1$ and $G 2$ was not significant $(p=0.06)$; The difference between $G 1$ and $G 3$ was significant $(p=0.01)$. The difference between $\mathrm{G} 2$ and $\mathrm{G} 3$ was not significant $(\mathrm{p}=0.71)$.

${ }^{3} \mathrm{BMI}$, Body mass index.

${ }^{4} \mathrm{MBP}$, Mean blood pressure.

${ }^{5} \mathrm{HDL}$, High density lipoprotein.

${ }^{6}$ hsCRP, High sensitivity C-reactive protein.

${ }^{7} \mathrm{HbA1c}$, Glycated hemoglobin.

${ }^{8} \mathrm{HOMA}-\mathrm{IR}$, Homeostatic model assessment for insulin resistance.

${ }^{9}$ Aspartate aminotransferase (AST) to alanine transaminase (ALT) ratio.

${ }^{10} \mathrm{ALT}$, Alanine transaminase.

${ }^{11}$ AST, Aspartate aminotransferase. 
Supplementary Table 5 . The relationship between age, testosterone, stress, BMI and cardiometabolic risk markers ( $\mathrm{N}=186$ ).

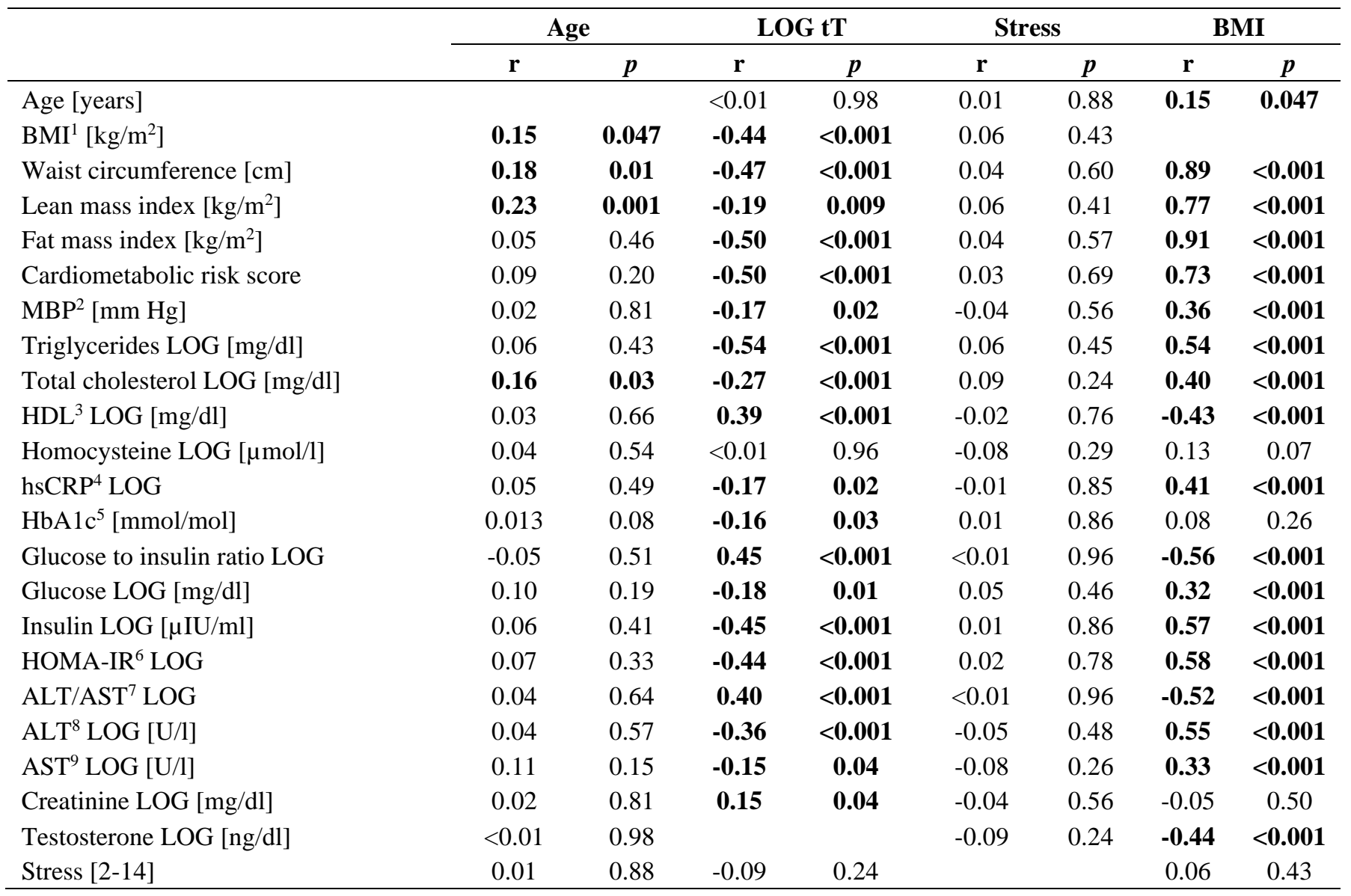

${ }^{1} \mathrm{BMI}$, Body mass index.

${ }^{2} \mathrm{MBP}$, Mean blood pressure.

${ }^{3} \mathrm{HDL}$, High density lipoprotein.

${ }^{4}$ hsCRP, High sensitivity C-reactive protein.

${ }^{5} \mathrm{HbA1C}$, Glycated hemoglobin.

${ }^{6} \mathrm{HOMA}-\mathrm{IR}$, Homeostatic model assessment for insulin resistance.

${ }^{7}$ Aspartate aminotransferase (AST) to alanine transaminase (ALT) ratio.

${ }^{8} \mathrm{ALT}$, Alanine transaminase.

${ }^{9} \mathrm{AST}$, Aspartate aminotransferase.

Significant results are bolded. 
Supplementary Table 6 . The results of correlation analyses for the relationship between LOG s-Klotho and markers of cardiometabolic risk and controlled variables ( $\mathrm{N}=186)$.

\begin{tabular}{|c|c|c|}
\hline & $\mathbf{r}$ & $p$ \\
\hline Waist circumference $[\mathrm{cm}]$ & 0.03 & 0.67 \\
\hline Triglycerides LOG & -0.14 & 0.06 \\
\hline Lean mass index $\left[\mathrm{kg} / \mathrm{m}^{2}\right]$ & 0.03 & 0.64 \\
\hline Fat mass index $\left[\mathrm{kg} / \mathrm{m}^{2}\right]$ & 0.01 & 0.93 \\
\hline $\mathrm{MBP}^{1}[\mathrm{~mm} \mathrm{Hg}]$ & 0.01 & 0.93 \\
\hline $\mathrm{HDL}^{2} \mathrm{LOG}[\mathrm{mg} / \mathrm{dl}]$ & 0.08 & 0.28 \\
\hline Glucose LOG [mg/dl] & 0.11 & 0.13 \\
\hline Insulin LOG $[\mu \mathrm{IU} / \mathrm{ml}]$ & 0.07 & 0.31 \\
\hline $\mathrm{ALT}^{3} \mathrm{LOG}[\mathrm{U} / \mathrm{l}]$ & -0.04 & 0.62 \\
\hline $\mathrm{AST}^{4} \mathrm{LOG}[\mathrm{U} / \mathrm{l}]$ & 0.08 & 0.25 \\
\hline
\end{tabular}

${ }^{1} \mathrm{MBP}$, Mean blood pressure.

${ }^{2} \mathrm{HDL}$, High density lipoprotein.

${ }^{3} \mathrm{ALT}$, Alanine transaminase.

${ }^{4} \mathrm{AST}$, Aspartate aminotransferase. 
Supplementary Table 7. The results of regression analysis for the relationship between s-Klotho and various measures of cardiometabolic risk, adjusted for age, BMI, alcohol use, physical activity and testosterone level ( $N=186)$.

\begin{tabular}{|c|c|c|c|c|}
\hline & $\boldsymbol{\beta}$ & $\mathrm{SE}(\boldsymbol{\beta})$ & $\mathbf{t}(\mathbf{1 7 9})$ & $p$ \\
\hline \multicolumn{5}{|c|}{ Model 1: Dependent variable: MBP: $F(6,179)=5.07$, adj. $R^{2}=0.12, p<0.001$} \\
\hline S-Klotho LOG $[\mathrm{pg} / \mathrm{ml}]$ & 0.03 & 0.07 & 0.48 & 0.63 \\
\hline Age [years] & -0.04 & 0.07 & -0.64 & 0.52 \\
\hline BMI $^{1}\left[\mathrm{~kg} / \mathrm{m}^{2}\right]$ & 0.35 & 0.08 & 4.47 & $<0.001$ \\
\hline Alcohol use & 0.12 & 0.07 & 1.61 & 0.11 \\
\hline Physical activity & 0.01 & 0.07 & 0.12 & 0.90 \\
\hline Total testosterone LOG [ng/dl] & -0.01 & 0.08 & -0.16 & 0.87 \\
\hline \multicolumn{5}{|c|}{ Model 2: Dependent variable: triglycerides LOG: $F(6,179)=22.95$, adj. $R^{2}=0.42, p<0.001$} \\
\hline S-Klotho LOG $[\mathrm{pg} / \mathrm{ml}]$ & -0.06 & 0.06 & -1.01 & 0.32 \\
\hline Age [years] & -0.001 & 0.06 & -0.01 & 0.99 \\
\hline $\operatorname{BMI}^{1}\left[\mathrm{~kg} / \mathrm{m}^{2}\right]$ & 0.36 & 0.06 & 5.68 & $<0.001$ \\
\hline Alcohol use & 0.14 & 0.06 & 2.31 & 0.02 \\
\hline Physical activity & -0.06 & 0.06 & -1.13 & 0.26 \\
\hline Total testosterone LOG [ng/dl] & -0.35 & 0.06 & -5.48 & $<0.001$ \\
\hline \multicolumn{5}{|c|}{ Model 3: Dependent variable: HDL LOG: $F(6,179)=9.90$, adj. $R^{2}=0.22, p<0.001$} \\
\hline S-Klotho LOG [pg/ml] & 0.06 & 0.07 & 0.88 & 0.38 \\
\hline Age [years] & 0.07 & 0.07 & 1.13 & 0.26 \\
\hline $\mathrm{BMI}^{1}\left[\mathrm{~kg} / \mathrm{m}^{2}\right]$ & -0.34 & 0.07 & -4.67 & $<0.001$ \\
\hline Alcohol use & 0.05 & 0.07 & 0.76 & 0.45 \\
\hline Physical activity & 0.06 & 0.07 & 0.88 & 0.38 \\
\hline Total testosterone LOG [ng/dl] & 0.22 & 0.07 & 2.94 & 0.004 \\
\hline \multicolumn{5}{|c|}{ Model 5: Dependent variable: Glucose LOG: $F(6,179)=4.90$, adj. $R^{2}=0.11, p<0.001$} \\
\hline S-Klotho LOG $[\mathrm{pg} / \mathrm{ml}]$ & 0.10 & 0.07 & 1.30 & 0.19 \\
\hline Age [years] & 0.05 & 0.07 & 0.64 & 0.52 \\
\hline $\mathrm{BMI}^{1}\left[\mathrm{~kg} / \mathrm{m}^{2}\right]$ & 0.29 & 0.08 & 3.65 & $<0.001$ \\
\hline Alcohol use & -0.07 & 0.07 & -0.95 & 0.34 \\
\hline Physical activity & -0.13 & 0.07 & -1.81 & 0.07 \\
\hline Total testosterone LOG [ng/dl] & -0.04 & 0.08 & -0.52 & 0.60 \\
\hline \multicolumn{5}{|c|}{ Model 6: Dependent variable: Insulin LOG: $\mathrm{F}(6,179)=19.84$, adj. $\mathrm{R}^{2}=0.38, p<0.001$} \\
\hline S-Klotho LOG [pg/ml] & 0.10 & 0.06 & 1.61 & 0.11 \\
\hline Age [years] & -0.02 & 0.06 & -0.28 & 0.78 \\
\hline BMI $^{1}\left[\mathrm{~kg} / \mathrm{m}^{2}\right]$ & 0.46 & 0.07 & 6.98 & $<0.001$ \\
\hline Alcohol use & -0.02 & 0.06 & -0.41 & 0.68 \\
\hline Physical activity & -0.11 & 0.06 & -1.89 & 0.06 \\
\hline Total testosterone LOG $[\mathrm{ng} / \mathrm{dl}]$ & -0.23 & 0.07 & -3.54 & $<0.001$ \\
\hline \multicolumn{5}{|c|}{ Model 7: Dependent variable: ALT LOG: $F(6,179)=14.51$, adj. $R^{2}=0.30, p<0.001$} \\
\hline S-Klotho LOG $[\mathrm{pg} / \mathrm{ml}]$ & -0.01 & 0.06 & -0.15 & 0.88 \\
\hline Age [years] & -0.03 & 0.06 & -0.55 & 0.59 \\
\hline BMI $^{1}\left[\mathrm{~kg} / \mathrm{m}^{2}\right]$ & 0.48 & 0.07 & 6.91 & $<0.001$ \\
\hline Alcohol use & 0.05 & 0.06 & 0.73 & 0.47 \\
\hline Physical activity & -0.10 & 0.06 & -1.63 & 0.10 \\
\hline Total testosterone LOG $[\mathrm{ng} / \mathrm{dl}]$ & -0.12 & 0.07 & -1.68 & 0.10 \\
\hline \multicolumn{5}{|c|}{ Model 8: Dependent variable: AST LOG: $F(6,179)=4.97$, adj. $R^{2}=0.11, p<0.001$} \\
\hline S-Klotho LOG [pg/ml] & 0.12 & 0.07 & 1.63 & 0.10 \\
\hline Age [years] & 0.04 & 0.07 & 0.56 & 0.57 \\
\hline $\operatorname{BMI}^{1}\left[\mathrm{~kg} / \mathrm{m}^{2}\right]$ & 0.30 & 0.08 & 3.77 & $<0.001$ \\
\hline Alcohol use & 0.16 & $\mathbf{0 . 0 7}$ & 2.17 & 0.03 \\
\hline Physical activity & -0.02 & 0.07 & -0.25 & 0.80 \\
\hline Total testosterone LOG [ng/dl] & -0.02 & 0.08 & -0.31 & 0.75 \\
\hline
\end{tabular}

${ }^{1}$ BMI, Body mass index. 